\title{
Degeneration of the pulmonary autograft: An explant study
}

\author{
Paul H. Schoof, MD, PhD, ${ }^{\text {a }}$ Johanna J. M. Takkenberg, MD, PhD, ${ }^{b}$ Robert-Jan van Suylen, MD, PhD, ${ }^{d}$ \\ Pieter E. Zondervan, MD, ${ }^{c}$ Mark G. Hazekamp, MD, PhD, ${ }^{a}$ Robert A. E. Dion, MD, and Ad J. J. C. Bogers, MD, PhD
}

Objective: We sought to determine the histologic features of pulmonary autografts explanted after the Ross operation.

Methods: Histologic sections of 30 explanted autografts and 8 normal heart valves were compared and semiquantitatively scored by a blinded cardiovascular pathologist.

Results: Pulmonary autografts $(\mathrm{n}=30)$ were explanted on average $6.1 \pm 0.6$ years (median, 6.6 years; range, 0.1-11.7 years) after the Ross operation $(\mathrm{n}=28)$ or removed at autopsy $(n=2)$. Twelve $(43 \%)$ of the patients undergoing reoperation had no or negligible autograft insufficiency on early transthoracic echocardiography, $12(43 \%)$ had grade 1 autograft insufficiency, and 4 (14\%) had grade 1-2 autograft insufficiency. Valve regurgitation with root dilatation was the most common indication for reoperation after root replacement $(n=26$ [93\%]) and regurgitation after subcoronary implanted autografts $(n=2[7 \%])$. Microscopy of the autograft explants revealed normal laminar architecture and cellularity. Wall specimens were characterized by reduced and fragmented elastin and increased collagen levels (fibrosis). Medial elastin changes were associated with the presence of hypertrophic smooth muscle cells. Fibrosis was most severe in the adventitia. Intimal thickening was a common finding. Valve explants showed significant thickening caused by fibrocellular tissue on the ventricular surface and marked thickening of the free margin. An autopsy explant with normal function before death showed similar features.

Conclusions: Pulmonary autograft explants showed severe aneurysmal degeneration of the wall, which was characterized by intimal thickening, medial elastin fragmentation, and adventitial fibrosis. Valve leaflets were thickened. The presence of these features in a nonfailing explant suggests these changes represent a common mode of

From the Department of Cardiothoracic Surgery, ${ }^{a}$ University Medical Center Leiden, Leiden, the Netherlands; the Departments of Cardiothoracic Surgery ${ }^{\mathrm{b}}$ and Pathology, Erasmus Medical Center, Rotterdam, the Netherlands; and the Department of $\mathrm{Pa}$ thology, ${ }^{\mathrm{d}}$ University Hospital Maastricht, Maastricht, The Netherlands.

Received for publication April 6, 2006; revisions received June 26, 2006; accepted for publication July 12, 2006.

Address for reprints: Paul H. Schoof, MD, $\mathrm{PhD}$, Department of Cardiothoracic Surgery, D6-50, Leiden University Medical Center, PO Box 9600, 2300 RC Leiden, the Netherlands (E-mail: P.H.Schoof@ lumc.nl).

J Thorac Cardiovasc Surg 2006;132:1426-32 $0022-5223 / \$ 32.00$

Copyright (C) 2006 by The American Association for Thoracic Surgery

doi:10.1016/j.jtcvs.2006.07.035 remodeling.

$\mathrm{N}$ eoaortic root dilatation has become a clinical hallmark after the Ross operation and a cause of growing concern. ${ }^{1-8}$ It can be progressive and is often associated with regurgitation of the autograft valve. Dilatation and regurgitation together constitute the primary cause of pulmonary autograft failure and the principal reason for reoperation after the Ross procedure. ${ }^{9}$ Furthermore, dissection has been reported as a possible complication of pulmonary autograft root aneurysm. ${ }^{10,11}$ The cause of dilatation, regurgitation, or both is not yet understood but has been related to bicuspid aortic valve disease and associated developmental errors, preoperative diagnosis of aortic valve insufficiency or aneurysm, surgical technique, intraoperative trauma, and primary tissue degeneration. ${ }^{3,5,12-15}$ We hypothesized pulmonary autograft failure to be related to pathologic changes in the wall and the valve.

We studied microscopic sections of explanted pulmonary autografts to identify pathologic features that could play a role in clinical failure and could serve in future studies. 
Abbreviations and Acronyms

$\mathrm{SD}=$ standard deviation

\section{Materials and Methods \\ Patients}

Pulmonary autografts of 30 patients from 4 centers were removed at reoperation $(n=28)$ or autopsy $(n=2)$ between May 1992 and January 2005. The involved centers performed 94\% $(n=416)$ of

Table 1. Demographic and preoperative and intraoperative data (autograft implantation)

\begin{tabular}{|c|c|}
\hline Variable & $\begin{array}{l}\text { No. of patients } \\
\text { (total, } n=30 \text { ) }\end{array}$ \\
\hline \multicolumn{2}{|l|}{ Age at autograft implantation (y) } \\
\hline Mean \pm SD & $24.5 \pm 10.3$ \\
\hline Range & $6.5-42.9$ \\
\hline Median & 25.8 \\
\hline \multicolumn{2}{|l|}{ Sex } \\
\hline Male & 18 \\
\hline Female & 12 \\
\hline \multicolumn{2}{|l|}{ Prior interventions } \\
\hline Aortic valvotomy & 3 \\
\hline Resection subvalvular membrane & 3 \\
\hline Balloon dilatation & 5 \\
\hline Aortic valve replacement & 3 \\
\hline Sinus of Valsalva fistula closure & 1 \\
\hline \multicolumn{2}{|l|}{ Cause } \\
\hline AS & 4 \\
\hline $\mathrm{Al}$ & 10 \\
\hline $\mathrm{AS} / \mathrm{Al}$ & 13 \\
\hline Prosthetic dysfunction & 3 \\
\hline \multicolumn{2}{|l|}{ Functional class } \\
\hline I & 21 \\
\hline II & 8 \\
\hline IV & 1 \\
\hline \multicolumn{2}{|l|}{ Native aortic valve morphology } \\
\hline Bicuspid & 15 \\
\hline Tricuspid & 15 \\
\hline \multicolumn{2}{|l|}{ Technique of autograft implantation } \\
\hline Root replacement & 28 \\
\hline Subcoronary & 2 \\
\hline \multicolumn{2}{|l|}{ Additional procedures } \\
\hline Ascending aorta reduction & 3 \\
\hline Annular enlargement & 2 \\
\hline Subvalvular membrane resection & 2 \\
\hline VSD closure & 1 \\
\hline \multicolumn{2}{|l|}{ Early autograft regurgitation } \\
\hline None & 2 \\
\hline Trace & 12 \\
\hline Grade 1 & 12 \\
\hline Grade $1-2$ & 4 \\
\hline
\end{tabular}

$S D$, Standard deviation; $A S$, aortic valve stenosis; $A l$, aortic valve insufficiency; $V S D$, ventricular septal defect. all Ross operations in the Netherlands between 1988 and $2001 .^{16}$ Patient characteristics and details on the Ross operation or autograft reoperation are given in Tables 1 and 2. Ross operations were performed as a root replacement $(n=28)$ with an unsupported freestanding autograft root by 10 different surgeons. Two patients had a subcoronary implantation of the pulmonary autograft. Surgical details on the mode of root implantation (on or within the aortic annulus) were not consistently described in the operative report. Echocardiographic analysis of early autograft valve function $(<2$ weeks after the operation) showed no or trace insufficiency in $12(42.9 \%)$ of 28 and grade 1 or more insufficiency in $16(57.1 \%)$ of 28 patients eventually undergoing reoperations for autograft failure. The autograft remained in place for a mean period of 6.1 years after the Ross operation (median, 6.6 years; range, 0.1-11.7 years). The most common indication for reoperation was regurgitation ( $\geq$ grade 2 ) with root dilatation (maximal echocardiographic diameter, $>40 \mathrm{~mm} ; \mathrm{n}=23$ ). Replacement of

Table 2. Preoperative and intraoperative data (surgical autograft explantation)

\begin{tabular}{|c|c|}
\hline Variable & $\begin{array}{l}\text { No. of patients } \\
\text { undergoing reoperation } \\
\text { (total, } \mathbf{n}=28 \text { ) }\end{array}$ \\
\hline \multicolumn{2}{|l|}{$\begin{array}{l}\text { Time interval until autograft } \\
\text { replacement }(y)\end{array}$} \\
\hline Mean \pm SD & $6.1 \pm 3.1$ \\
\hline Range & $0.1-11.7$ \\
\hline Median & 6.6 \\
\hline \multicolumn{2}{|l|}{ Functional class } \\
\hline I & 15 \\
\hline II & 10 \\
\hline III & 3 \\
\hline \multicolumn{2}{|l|}{ Root dilatation (M-mode) } \\
\hline $40-50 \mathrm{~mm}$ & 7 \\
\hline $50-60 \mathrm{~mm}$ & 14 \\
\hline$\geq 60 \mathrm{~mm}$ & 4 \\
\hline Valve regurgitation $\geq$ grade 2 & 27 \\
\hline \multicolumn{2}{|l|}{ Surgeon's description } \\
\hline Root dilatation & 20 \\
\hline \multicolumn{2}{|l|}{ Valve abnormalities } \\
\hline Yes & 7 \\
\hline No & 21 \\
\hline \multicolumn{2}{|l|}{ Operative procedure } \\
\hline Autograft valve replacement & 8 \\
\hline Mechanical & 7 \\
\hline Bioprosthesis & 1 \\
\hline Root replacement & 18 \\
\hline Mechanical & 15 \\
\hline Bioprosthesis & 1 \\
\hline Allograft & 2 \\
\hline Valve-sparing root reconstruction & 2 \\
\hline \multicolumn{2}{|l|}{ Additional procedures } \\
\hline Pulmonary allograft replacement & 6 \\
\hline Mitral valve repair & 2 \\
\hline Aortic reduction & 2 \\
\hline
\end{tabular}

$S D$, Standard deviation. 
the entire autograft root was performed in $18(64.3 \%)$ of 28 patients undergoing reoperation. In 8 patients only the valve was replaced, and in 2 patients a valve-sparing root reconstruction was performed. One of the 8 patients needed a subsequent root replacement for aneurysmal autograft dilatation (66-mm diameter) 4 years after isolated autograft valve replacement. In 2 patients failure of the autograft was associated with systemic inflammatory disease (rheumatic fever ${ }^{17}$ in 1 and Reiter syndrome in 1). At gross inspection, the explanted autograft valve looked normal to the surgeon in 21 of 28 patients undergoing reoperation. In 7 patients the valve showed an unrecognized quadricuspid valve $(n=1)$, prolapse of 1 or more cusps ( $n=3$, one subcoronary implant), or cusp retraction ( $\mathrm{n}=3$, in 2 associated with inflammatory disease ${ }^{17}$ ). Two explants were obtained at autopsy; one patient with juvenile rheumatoid arthritis died of heart failure 6 months after the Ross operation because of severe regurgitation caused by rheumatic involvement of the autograft. ${ }^{18}$ Another patient with good autograft function died 5 years after an extended Ross operation from pulmonary thromboembolism after stenting of a pulmonary artery branch stenosis. There was no hospital mortality related to the reoperations.

\section{Histology}

Histologic sections used for clinical pathologic evaluation were reevaluated. Hematoxylin and eosin, elastin van Gieson, Picrosirius red, and Alcian blue stains were available in most autografts or were additionally performed in case they were lacking or of poor quality. Fibrosis in the adventitia, medial elastin fragmentation, fibrosis, mucopolysaccharide accumulation, and smooth muscle cell morphology and intimal hyperplasia of the wall were semiquantitatively scored (Table 3 ).

Nondiseased pulmonary $(n=5)$ and aortic $(n=3)$ valves discarded for clinical use by the Dutch Heart Valve Bank in Rotterdam served as control specimens. Use of these allografts for the purpose of this study was approved by the Dutch Heart Valve Bank ethical committee. Similar stains as for autograft sections were used for control sections. Histologic evaluation was performed with a Leica DM 6000B light microscope (Leica Microsystems, Wetzlar, Germany) by 3 observers, one of them a cardiovascular pathologist blinded to the origin of the material.

Histologic changes were semiquantitatively scored with the use of the criteria formulated by Schlatmann and Becker ${ }^{19}$ and de Sa and colleagues ${ }^{12}$ and supplemented by us with grading of adventitia fibrosis and intimal hyperplasia. Considering the histologic difference in medial elastin structure and valve morphology of the normal pulmonary artery and aorta, only pulmonary controls were used to score elastin fragmentation and valve parameters. Two explants showing rheumatic inflammation were excluded from the analysis.

The following criteria were used.

\section{Wall}

Adventitia. Fibrosis of the adventitia was examined in Picrosirius red-stained sections at $70 \times$ magnification: grade I, thickness was comparable with that of control aortic and pulmonary samples; grade II, adventitial collagen comprised less than half the width (= thickness) of the media; and grade III, adventitial collagen comprised more than half the width of the media.
Table 3. Histologic features of pulmonary autograft explants

\begin{tabular}{|c|c|c|c|c|}
\hline Variable & Grade & $\begin{array}{l}\text { Autograft } \\
\text { (n) }\end{array}$ & $\begin{array}{c}\text { Control } \\
\text { (n) }\end{array}$ & $P$ value* \\
\hline \multicolumn{5}{|l|}{ Wall ( $n=22)$} \\
\hline \multirow[t]{3}{*}{ Adventitia fibrosis } & I & 3 & 8 & $<.001$ \\
\hline & II & 11 & 0 & \\
\hline & III & 8 & 0 & \\
\hline \multicolumn{5}{|l|}{ Media } \\
\hline \multirow[t]{3}{*}{ Fibrosis } & I & 12 & 8 & .022 \\
\hline & II & 10 & 0 & \\
\hline & III & 0 & 0 & \\
\hline \multirow[t]{3}{*}{ Elastin fragmentation $†$} & I & 5 & 5 & .004 \\
\hline & II & 12 & 0 & \\
\hline & III & 5 & 0 & \\
\hline \multirow[t]{3}{*}{ MPS accumulation } & I & 10 & 6 & .12 \\
\hline & II & 8 & 2 & \\
\hline & III & 4 & 0 & \\
\hline \multirow[t]{3}{*}{ SMC morphology } & I & 7 & 7 & .009 \\
\hline & II & 10 & 1 & \\
\hline & III & 5 & 0 & \\
\hline \multirow[t]{3}{*}{ Intimal thickness } & I & 1 & 7 & $<.001$ \\
\hline & II & 14 & 1 & \\
\hline & III & 7 & 0 & \\
\hline \multicolumn{5}{|l|}{ Valve $(\mathrm{n}=26) \dagger$} \\
\hline \multirow[t]{2}{*}{ Fibrosa thickening } & + & 9 & 0 & .29 \\
\hline & - & 17 & 5 & \\
\hline \multirow[t]{2}{*}{ Spongiosa thickening } & + & 7 & 0 & .56 \\
\hline & - & 19 & 5 & \\
\hline \multirow[t]{2}{*}{ Ventricularis thickening } & + & 23 & 0 & $<.001$ \\
\hline & - & 3 & 5 & \\
\hline \multirow[t]{2}{*}{ Free rim thickening } & + & 17 & 0 & .008 \\
\hline & - & 9 & 5 & \\
\hline
\end{tabular}

MPS, Mucopolysaccharide; SMC, smooth muscle cell. * $\chi^{2}$ Test or Fisher exact test. $\dagger P$ valves only were used for comparison.

Media. Fibrosis was graded in Picrosirius red-stained sections at $70 \times$ magnification: grade I, collagen areas together represented less than one third of total medial width; grade II, collagen areas together represented between one third and two thirds of total width; and grade III, the estimated stained area exceeded two thirds of the medial surface.

Elastin fragmentation was graded at $70 \times$ magnification: grade I, elastin medial architecture was comparable with that of the normal pulmonary wall; grade II, increased fragmentation and overall reduction of elastin was present; and grade III, the media showed predominant or complete lack of elastin.

Acid mucopolysaccharide accumulations graded in Alcian blue stains at $70 \times$ magnification were defined as follows: grade I, minute foci of mucoid material were present not more in width than 1 lamellar unit; grade II, pools of mucoid material covering more than the width of a single lamellar unit but less than 3 units; and grade III, large pools of mucoid material more than 3 lamellar units in width.

Smooth muscle cell morphology was graded at $240 \times$ magnification in van Gieson-stained sections as follows: grade I, small 
foci with change in the orientation of smooth muscle cells; grade II, 1 or several areas of cellular reorientation together representing between one third and half the thickness of the media; grade III, a large area of cellular reorientation consisting of more than half the medial thickness.

\section{Intima}

Thickening of the intima was graded as follows: grade I, the intima was not thickened; grade II, intima was less than one half of the medial width; and grade III, intima was more than one half of the medial width.

\section{Valve}

Valves were assessed with respect to thickening of the fibrosa, spongiosa, and ventricularis, which was present $(+)$ or absent $(-)$ with a width at least twice the corresponding layer of control pulmonary valves. Cuspal free margin thickening was present $(+)$ or absent (-).

\section{Statistical Analysis}

Continuous variables are presented as means \pm standard deviation (SD), and discrete variables are presented as proportions unless stated otherwise. Histologic findings of autografts and control specimens were compared by using the Mann-Whitney $U$ test (wall samples) or the Fisher exact test (valve samples). The association between time to explantation and severity of histologic changes was calculated with 1-way analysis of variance and simple linear regression. All tests were 2 -sided, and a $P$ value of less than .05 was considered significant.

\section{Results}

\section{General Features}

Microscopic sections of both the autograft wall and valve were available in 20 patients, of only the wall in 2 patients, and of only the valve in 6 patients (total wall sections, $\mathrm{n}=$ 22; total valve sections, $\mathrm{n}=26$ ).

There was a striking difference between the wall of the autograft and the normal aortic wall, with the autograft being typically thinner and containing less elastin (Figure 1). Accordingly, autograft valves showed no similarity with aortic valves of control specimens. Instead, the pulmonary valve was only thickened by tissue apposition on the ventricular surface. The severity of the histologic changes appeared unrelated to the age of the patient or the presence or absence of a bicuspid native aortic valve. There was a trend toward a longer mean time to explantation in those wall specimens that had more mucopolysaccharide accumulation (grade I vs II vs III: 7.2 years [SD, 1.8] vs 7.2 years [SD 2.4] vs 10.1 years [SD 2.6]; $P=.09$ ). There was a significantly longer mean time to explantation in those valve specimens that had ventricularis thickening (7.1 years [SD 3.0] vs 2.5 years [SD 4.1]; $P=.03$ ).

A histologic wall score was obtained by adding up all 6 wall scores. The higher the score (defined as more wall abnormalities), the longer the mean time to explantation
$(P=.10)$. A valve score was obtained by adding up the 3 valve scores. No association was found between valve scores and mean time to autograft explantation.

Cystic medial necrosis, atherosclerosis, or calcification was uniformly absent. Instead, explants showed retained laminar architecture with apparently normal cellularity of wall and valve. Inflammatory infiltrates were only present in the valves of a patient with a relapse of rheumatic fever and a patient with juvenile rheumatoid arthritis, demonstrating the susceptibility of the pulmonary autograft to rheumatic inflammation. ${ }^{17,18}$ These explants were excluded from the analysis.

Dissection of the autograft wall was a macroscopic finding at reoperation in 1 patient and confirmed at microscopy.

\section{Segmental Wall Analysis}

Adventitia. Abundant fibrosis, absent in control specimens and much less in native aortic wall specimens of the same patient, was commonly present along the entire wall of the pulmonary autograft ( $\geq$ grade II in 19/22 patients, $P<$ .001). The fibrosis was most extreme near the media, where the individual collagen fibers typically merged into a dense confluent layer. Vasa vasorum were present in number and distribution comparable with those seen in control specimens (Figure 1).

Media. Collagen density was more pronounced in autografts than in control pulmonary or aortic walls ( $\geq$ grade II in $10 / 22$ vs $0 / 8, P=.022$ ). The most prominent feature in the media was the reduction and fragmentation of elastin. The autograft in this respect looked distinctly different from both native aorta and control pulmonary artery ( $\geq$ grade II in $17 / 22$ compared with $0 / 5$ pulmonary controls, $P=.004$ ). The scarce elastin fragments were equally distributed throughout the media. Cysts were absent (Figure 1). Smooth muscle cells showed a typical morphology. In contrast to those in control sections, they were hypertrophic and appeared aligned in a radial instead of longitudinal direction ( $\geq$ grade II in $15 / 22, P=.009$; Figure 1 ). Accumulations of acid mucopolysaccharides (myxomatous degeneration) of grade II or greater was present in 12 of 22 autograft specimens versus 2 of 8 control specimens $(P=.12)$.

Intima. The intima of the autograft was thickened in the majority of patients ( $\geq$ grade II in 21/22 versus $1 / 7$ control specimens, $P<.001)$ also at a distance from the anastomosis. The neointima contained myofibroblasts and stained positive for collagen.

Valve. The valve showed retained laminar architecture and interstitial cellularity but was thickened by tissue apposition on the ventricular surface. The extra layer, irregular in thickness and extension, was present in the majority of specimens $(23 / 26$ versus $0 / 5$ control specimens, $P<.001)$ and sometimes caused a significant thickness increase. Like 


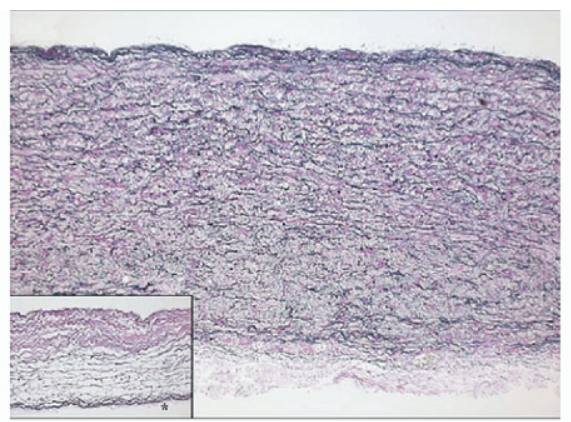

Normal pulmonary artery wall and valve *

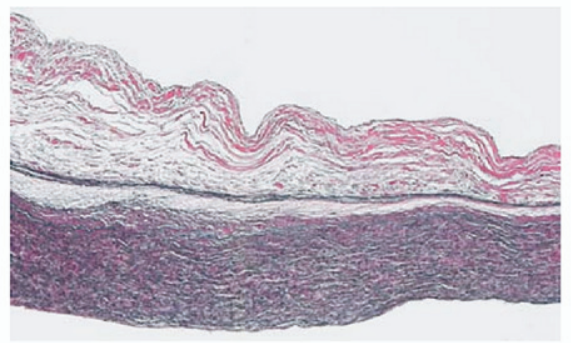

Valve

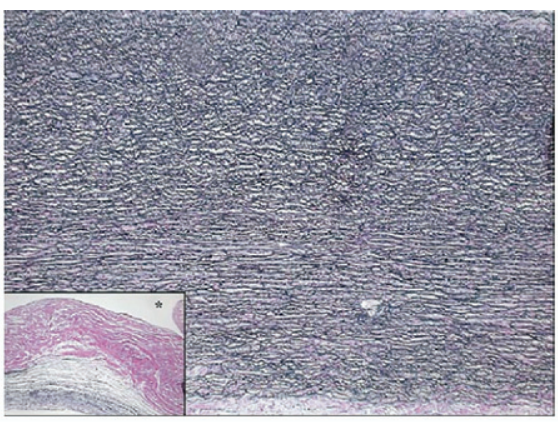

Normal aortic wall and valve *

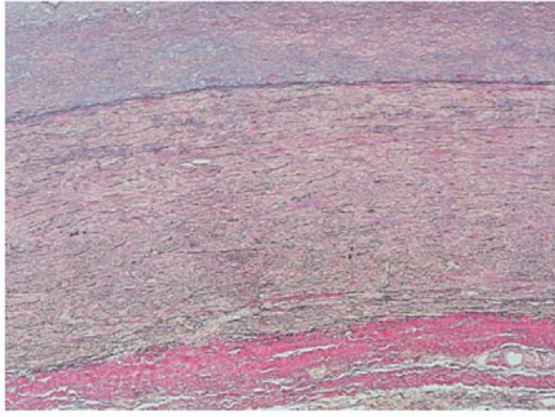

Wall

Pulmonary autograft

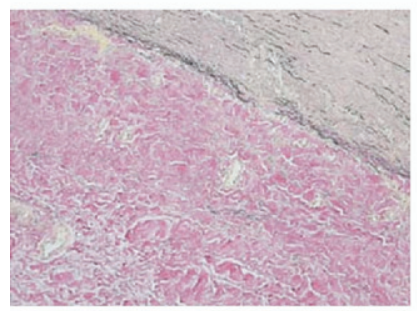

Adventitia

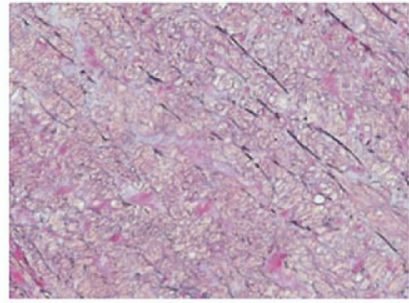

Media

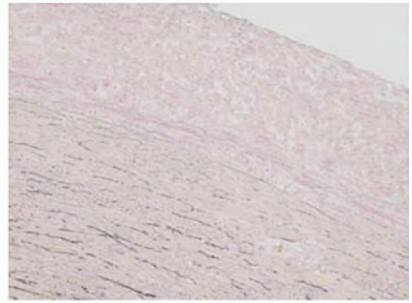

Intima

Figure 1. Normal aortic and pulmonary walls and valves (upper panels) compared with micrographs of a pulmonary autograft explanted 11 years and 9 months after the Ross operation showing representative histopathologic features. (Resorcin-Fuchsin, $60 \times$ and $240 \times$ magnification.) The valve is moderately thickened by elastin-rich tissue on the ventricular surface (middle left panel). The adventitia contains vasa vasorum and shows extensive fibrosis. Elastin in the media is significantly reduced and fragmented and replaced by hypertrophic smooth muscle cells. The intima is thickened (middle right and lower panels).

intimal hyperplasia, it contained myofibroblasts and proteoglycans but also stained for elastin and collagen (Figure 1).

Changes in the 2 subcoronary explants were more severe, with grossly disturbed laminar architecture and considerable sclerotic thickening. Fibrosa and spongiosa thickening was less frequently found and did not differ from that seen in control specimens (9/26 and 7/26, respectively; $P=.29$ and $P=.56)$. Most cusps had club-like thickening of the free margin of the valve (17/26 versus $0 / 8$ control specimens, $P=.008)$ containing fibroblasts and collagen.

\section{Discussion}

The present study demonstrates that most explanted pulmonary autografts show histologic changes that are not found in normal valves. The autograft valve showed increased thickness as the most remarkable feature but did not look like a true aortic valve. Instead, the delicate pulmonary valve architecture was maintained, which was thickened by an additional layer of fibrocellular tissue on the ventricular surface (Figure 1). A similar phenomenon was reported by Chambers and associates ${ }^{20}$ in an autograft removed after 26 
years, who described it as "fibrosis and thickening of the adventitia" (Figure 7 of their publication); by RabkinAikawa and coworkers, ${ }^{21}$ who described the intimal thickening on the ventricular aspect as pannus; and by Goffin and colleagues, ${ }^{22}$ attributing "enlargement of the ventricularis" to the effect of jet lesion. These are various interpretations of a similar observation, which we think is an important effect of adaptive remodeling of the autograft valve. It is probably the result of attempted restoration of normal stress strain relations after the increase of tensile and shear stress in the systemic circulation. It might enhance mechanical strength but also influence valve function by restricting radial extensibility. Therefore it might play a role in the cause of pulmonary autograft regurgitation.

Changes in the wall of the autograft were more severe. First of all, in accordance with valvular changes, the wall showed no resemblance with either normal pulmonary or normal aortic walls. This important observation was made before in animals. ${ }^{15}$ It is important because it underlines that the aortic and pulmonary valves are distinctly different structures and that the fact that the aortic and pulmonary roots arise from a common embryologic trunk does not mean that the pulmonary valve can become a morphologic aortic valve. Instead, the pulmonary wall showed increased collagen content and loss of elastin. The resulting neoaortic wall had lost the typical characteristics of a large elastic artery, missing a robust elastin-rich media and a delicate adventitia, and showed severe degenerative changes instead. Loss and fragmentation of medial elastin are important histopathologic features in both pulmonary and abdominal, as well as in thoracic, aortic aneurysms. ${ }^{23-25}$ Autograft aneurysms might share a similar clinical behavior with a tendency toward progressive dilatation, compression, and rupture or dissection. This has indeed been observed in pulmonary autograft roots. ${ }^{10,11}$

The observed increase in collagen and loss of elastin might have functional implications and might theoretically limit the distensibility of the root. This has been confirmed by means of magnetic resonance imaging of pulmonary autograft roots in patients. ${ }^{26}$ Increased root stiffness in turn influences valve function and valve stress and might therefore also contribute to valve failure by accelerating degenerative changes. ${ }^{27}$

Smooth muscle cells, the principal collagen- and elastinproducing cells of the vascular wall, showed a typical morphology in the autograft wall. They were hypertrophic and appeared realigned, indicating a rearrangement of the cytoskeleton as a sign of cellular activity. Whereas a quiescent cellular state would be expected after completion of autograft adaptation, 12 years after the Ross operation, cellular hypertrophy was still visible (Figure 1). Similar smooth muscle cell hypertrophy was observed in aortic aneurysmal wall-derived smooth muscle cells,${ }^{28}$ confirming the aneu- rysmal nature of the autograft roots. Smooth muscle cells of autografts possibly remain involved in matrix production as a result of failure to reestablish wall stress homeostasis. A continuous demand of matrix-producing cells might accelerate senescence and eventually cause the production of poor-quality structural proteins unable to maintain adequate wall integrity. This could be an explanation for the tendency of autografts to become aneurysmal. A similar pathobiologic mechanism might play a role in valvular interstitial cells. Such an assumption is supported by Rabkin-Aikawa and associates, ${ }^{21,29}$ who observed that levels of the matrixremodeling enzyme matrix metalloproteinase 13 of pulmonary autograft valves did not return to the baseline levels of normal control valves up to 6 years after autograft implantation.

Interestingly, both aneurysmal and nonaneurysmal autograft wall sections showed similar pathologic changes in our study. Rabkin-Aikawa and associates ${ }^{21}$ also found comparable changes in autografts that were either removed at surgical intervention or at autopsy or transplantation, which also suggests that a common mode of adaptive remodeling might play a role that can eventually cause degeneration.

On the basis of our findings, we can speculate on the cause of aneurysmal autograft wall degeneration. Failing of the remodeling process might be related to the fact that pulmonary autograft cells lack the genetic characteristics to adequately address the functional needs required in the left ventricular outflow tract. Adaptation of the pulmonary root to these left ventricular outflow tract conditions might in fact be beyond biologic allowance and perhaps be as demanding as adaptation of the right ventricle to function as a left ventricle. It might work for a long time but eventually fails relatively early in many. In this regard it would also be very interesting to assess the function of the pulmonary valve in the systemic circulation long term after the arterial switch operation, the Damus-Kaye-Stansel operation, or the Norwood operation to compare pulmonary autograft pathology with that of other pulmonary valves that were made to function in the systemic circulation.

We conclude that the pulmonary autografts we explanted because of clinical failure and at autopsy showed aneurysmal degeneration of the wall and significant microscopic thickening of the valve.

Future studies should validate our observations and suppositions. Transcriptional biomarkers involved in aneurysmal autograft dilatation and valve dysfunction could be determined by means of microarray technology. Matrix analysis is required to qualify and quantify our light microscopic observations.

Tissue harvesting was performed by 10 different surgeons and processing and staining by 4 different pathologic services. The resulting sample heterogeneity is an important limitation to this study. We used a gross type of semiquan- 
titative grading system, providing only a semiquantitative impression of major pathologic features. Control specimens were not from age-matched subjects, which could have introduced incorrections with respect to the observed discrepancies.

On behalf of the Dutch Ross Study Group, we thank Peter de Bruin and Karl Dossche (St Antonius Hospital, Nieuwegein), Vincent Smit (University Medical Center Leiden), Herbert van Wetten (University Medical Center Radboud Nijmegen), and Margot Bartelings and Adri Gittenberger-de Groot (University Medical Center Leiden) for providing tissue sections. Egbert Bos and Bas Mochtar (Erasmus Medical Center Rotterdam), Aagje Nijveld and Sandeep Singh (University Medical Center Radboud Nijmegen), and Marc Schepens and Aart Brutel de la Rivière (St Antonius Hospital Nieuwegein) were the nonauthor implanting surgeons. We also thank the Dutch Heart Valve Bank (Sjors van Kats) for providing control heart valves.

\section{References}

1. Elkins RC, Lane MM, McCue C. Pulmonary autograft reoperation: incidence and management. Ann Thorac Surg. 1996;62:450-5.

2. Hokken RB, Takkenberg JJ, vanHerwerden LA, Roelandt JR, Bogers AJ. Excessive pulmonary autograft dilatation causes important aortic regurgitation. Heart. 2003;89:933-4.

3. David TE, Omran A, Ivanov J, Armstrong S, de Sa MP, Sonnenberg $\mathrm{B}$, et al. Dilation of the pulmonary autograft after the Ross procedure. J Thorac Cardiovasc Surg. 2000;119:210-20.

4. Simon-Kupilik N, Baily J, Moidl R, Kasimir MT, Mittlbock M, Seebacher G, et al. Dilatation of the autograft root after the Ross operation. Eur J Cardiothorac Surg. 2002;21:470-3.

5. Luciani GB, Casali G, Favaro A, Prioli MA, Barozzi L, Santini F, et al. Fate of the aortic root late after Ross operation. Circulation. 2003;108(suppl 1):II61-7.

6. Kouchoukos NT, Masetti P, Nickerson NJ, Castner CF, Shannon WD, Davila-Roman VG. The Ross procedure: long-term clinical and echocardiographic follow-up. Ann Thorac Surg. 2004;78:773-81.

7. Settepani F, Kaya A, Morshuis WJ, Schepens MA, Heijmen RH, Dossche KM. The Ross operation: an evaluation of a single institution's experience. Ann Thorac Surg. 2005;79:499-504.

8. Hazekamp MG, Grotenhuis HB, Schoof PH, Rijlaarsdam ME, Ottenkamp J, Dion RA. Results of the Ross operation in a pediatric population. Eur J Cardiothorac Surg. 2005;27:975-9.

9. The International Registry for the Ross Procedure. Available at: www.rossregistry.com. Accessed July 1, 2005.

10. Kincaid EH, Maloney JD, Lavender SW 2nd, Kon ND. Dissection in a pulmonary autograft. Ann Thorac Surg. 2004;77:707-8.

11. Luciani GB, Favaro A, Viscardi F, Bertolini P, Mazzucco A. Valvesparing root replacement for pulmonary autograft dissection late after the Ross operation. J Thorac Cardiovasc Surg. 2004;128:753-6.

12. de Sa M, Moshkovitz Y, Butany J, David TE. Histologic abnormalities of the ascending aorta and pulmonary trunk in patients with bicuspid aortic valve disease: clinical relevance to the Ross procedure. J Thorac Cardiovasc Surg. 1999;118:588-94.

13. Luciani G, Barozzi L, Tomezolli A, Casali G, Mazzucco A. Bicuspid aortic valve disease and pulmonary autograft root dilatation after the Ross procedure: a clinicopathologic study. J Thorac Cardiovasc Surg. 2001;122:74-9.

14. Bogers AJ, Kappetein AP, Roos-Hesselink JW, Takkenberg JJ. Is a bicuspid aortic valve a risk factor for adverse outcome after an autograft procedure? Ann Thorac Surg. 2004;77:1998-2003.

15. Schoof PH, Gittenberger-De Groot AC, De Heer E, Bruijn JA, Hazekamp MG, Huysmans HA. Remodeling of the pulmonary autograft wall in the aortic position. J Thorac Cardiovasc Surg. 2000; 120:55-65

16. Takkenberg JJ, Dossche KM, Hazekamp MG, Nijveld A, Jansen EW, Waterbolk TW, et al. Report of the Dutch experience with the Ross procedure in 343 patients. Eur J Cardiothorac Surg. 2002;22:70-7.

17. de Vries H, Bogers AJ, Schoof PH, Mochtar B, Spitaels SE, Perlroth MG, et al. Pulmonary autograft failure caused by a relapse of rheumatic fever. Ann Thorac Surg. 1994;57:750-1.

18. van Suylen RJ, Schoof PH, Bos E, Frohn Mulder OM, den Hollander JC, Herzbergerten Cate R, et al. Pulmonary autograft failure after aortic root replacement in a patient with juvenile rheumatoid arthritis. Eur J Cardiothorac Surg. 1992;6:571-2.

19. Schlatmann TJ, Becker AE. Histologic changes in the normal aging aorta: implications for dissecting aortic aneurysm. Am J Cardiol. 1977;39:13-20.

20. Chambers JC, Somerville J, Stone S, Ross DN. Pulmonary autograft procedure for aortic valve disease: long-term results of the pioneer series. Circulation. 1997;96:2206-14.

21. Rabkin-Aikawa E, Aikawa M, Farber M, Kratz JR, Garcia-Cardena G, Kouchoukos NT, et al. Clinical pulmonary autograft valves: pathologic evidence of adaptive remodeling in the aortic site. $J$ Thorac Cardiovasc Surg. 2004;128:552-61.

22. Goffin YA, Narine KR, Alexander JP, Van Goethem J, Daenen WJ. Histopathologic comparison of a pulmonary autograft and pulmonary homograft in a patient 17 months after a Ross procedure: an autopsy study. J Heart Valve Dis. 1998;7:327-30.

23. Veldtman GR, Dearani JA, Warnes CA. Low pressure giant pulmonary artery aneurysms in the adult: natural history and management strategies. Heart. 2003;89:1067-70.

24. Campa JS, Greenhalgh RM, Powell JT. Elastin degradation in abdominal aortic aneurysms. Atherosclerosis. 1987;65:13-21.

25. Tang PC, Coady MA, Lovoulos C, Dardik A, Aslan M, Elefteriades JA, et al. Hyperplastic cellular remodeling of the media in ascending thoracic aortic aneurysms. Circulation. 2005;112:1098-105.

26. Reid SA, Walker PG, Fisher J, Nagy ZL, Ridgway ZP, Sivananthan MU, et al. Quantification of pulmonary autograft characteristics using magnetic resonance imaging. J Heart Valve Dis. 2004;13:78-85.

27. Fokin AA, Robicsek F, Cook JW, Thubrikar MJ, Schaper J. Morphological changes of the aortic valve leaflets in non-compliant aortic roots: in-vivo experiments. J Heart Valve Dis. 2004;13:444-51.

28. Liao S, Curci JA, Kelley BJ, Sicard GA, Thompson RW. Accelerated replicative senescence of medial smooth muscle cells derived from abdominal aortic aneurysm as compared to the adjacent inferior mesenteric artery. J Surg Res. 2000;92:85-95.

29. Rabkin-Aikawa E, Farber M, Aikawa M, Schoen FJ. Dynamic and reversible changes of interstitial cell phenotype during remodeling of cardiac valves. J Heart Valve Dis. 2004;13:841-7. 